\title{
Malignant Mastocytosis
}

National Cancer Institute

\section{Source}

National Cancer Institute. Malignant Mastocytosis. NCI Thesaurus. Code C8991.

Malignant neoplasm originating from mast cells. 